\author{
ПСИХОЛОГІЧНІ ОСОБЛИВОСТІ МІЖОСОБИСТІСНОГО СПІЛКУВАННЯ \\ ДІТЕЙ ДОШКІЛЬНОГО ВІКУ З ГІПЕРАКТИВНИМ РОЗЛАДОМ \\ ІЗ ДЕФІЦИТОМ УВАГИ \\ PSYCHOLOGICAL FEATURES OF INTERPERSONAL COMMUNICATION \\ OF PRESCHOOL CHILDREN WITH HYPERACTIVE DISORDER \\ WITH ATTENTION DEFICIT
}

УДК 159.9

DOI https://doi.org/10.32843/2663-

6085/2019.21.2-11

\section{Андрейко Б.В.,}

канд. психол. наук,

доцент кафедри спеціальної освіти

та соціальної роботи

Львівського національного

університету імені Івана Франка

Біль А.P.,

студентка IV курсу педагогічного

факультету

Львівського національного

університету імені Івана Франка
Стаття присвячена одній з актуальних проблем спілкування дітей дошкільного віку з ГРДУ. Зокрема, розкривається сутність таких понять, як гіперактивний розлад з десріцитом уваги, роль спілкування дитини з ГРДУ з ї однолітками. Акцентуємо увагу й на тому, що ця проблема в цей період часу набуває особливої актуальності, оскільки число гіперактивних дітей з кожним роком зростає.

Проте у статті також розписано про те, що гіперактивний розлад та дефіцит уваги (ГРДУ) є одним з найбільш поширених психоневрологічних розладів $і$ виступає найчастішою причиною порушень поведінки i труднощів навчання в дошкільному, а також і в молодшому шкільному віці, проблем у відносинах з оточуючими, а особливо у формуванні заниженої самооцінки.

Психологічні особливості гіперактивної дитини старшого дошкільного віку значно відрізняються від дошкільника з типовим розвитком. Адже такі малюки є дуже активними, непосидючими, їм важко стримати свою увагу, вони часто відволікаються на сторонні подразники. Не дивлячись на те, що вони проявляють інтерес до спілкування, невміння себе контролювати може при звести до суперечливості. Через це у дітей часто виникають конфрлікти з однолітками. Однак спілкування відіграє важливу роль у житті дитини старшого дошкільного віку з ГРду. Воно допомагає дитині дізнатися більше інформації, розвиватися психологічно, встановлювати контакт з іншими людьми і так далі.

У статті висвітлюються структурні компоненти, критерії, показники та рівні сорормованості досліджуваного явища. Основним завданням було проаналізувати літературу цієї проблематики, а також визначити за допомогою різноманітних методик психологічні особливості міжособистісного спілкування дітей дошкільного віку з ГРДУ з однолітками.
Ключові слова: діти дошкільного віку, спілкування, гіперактивний розлад з дефріцитом уваги, самооцінка.

The article is devoted to one of the topical problems of communication of preschool children with GRDU. In particular, the essence of such concepts as hyperactive disorder with attention deficit, the role of communication of a child with GRDU with its peers is revealed. We also emphasize that this problem is especially relevant in this period of time, as the number of hyperactive children is increasing every year. However, the article also states that hyperactive disorder and attention deficit (GRDU) is one of the most common psychoneurological disorders and is the most common cause of behavioral disorders and learning difficulties in preschool, as well as in younger school age, problems with others, and especially in the formation of low self-esteem.

Psychological features of a hyperactive child of preschool age are significantly different from a preschooler with typical development. After all, these babies are very active, restless, they find it difficult to keep their attention, they are often distracted by extraneous stimuli. Despite their interest in communication, failure to control themselves can lead to controversy. Because of this, children often have conflicts with their peers. However, communication plays an important role in the life of a preschool child with GRDU. It helps the child to find out more information, to develop psychologically, to make contact with other people, etc.

The article describes the structural components, criteria, indicators and levels of formation of the phenomenon under study. The main task was to analyze the literature of this issue, as well as to identify with the help of various methods the psychological features of interpersonal communication of preschool children with GRDU with their peers.

Key words: preschool children, communication, attention deficit hyperactive disorder, selfesteem.
Постановка проблеми в загальному вигляді. Проблема ГРДУ на цей час набуває особливої актуальності, оскільки число гіперактивних дітей з кожним роком зростає. Доведено й те, що ознаки ГРДУ найбільш виражені в дошкільному віці й припадають на період підготовки до вступу в шкільний заклад. Таким дітям зазвичай важко адаптуватися до навчання, адже цей синдром виражається в підвищеній рухливості.
Незважаючи на те, що проблемою гіперактивних дітей займається широке коло спеціалістів (такі як педіатр, психіатр, невролог, а також психолог і спеціалісти галузі вікової фрізіології), єдиної думки стосовно вивчення причин цього відхилення поки що не існує. Оскільки причин ГРДУ багато.

Проте батьки дошкільників з гіперактивним розладом із дефіцитом уваги також страждають через поведінку своїх дітей. Не можна заперечити й того, 
що народження дитини з порушеннями в розвитку завжди є стресом для сім'ї.

Найчастіше ГРДУ у малюків супроводжується проблемами у взаєминах з людьми, які їх оточують. Дітям дошкільного віку з типовим розвитком важко встановити контакт з дітьми, у яких є прояви гіперактивного розладу з десріцитом уваги. Адже такі дошкільники завжди є рухливими, неспокійними, переживають почуття страху, тривожність, напруженість.

Аналіз останніх досліджень та публікацій. Зазначеною проблематикою цікавилось багато дослідників зі сорери медицини та педагогіки із середини 19 ст.

Вперше у 1845 році німецький лікар Г. Хофроман описав у поетичній фрормі одну надзвичайно рухливу дитину і дав їй назву «Непосидько Філіп». 3 часом Ф. Шульцом була видана книга «Недоліки в характері дитини. Друга золота книга», в якій він досліджує групу дітей, яких у підсумку називає «неспокійними дітьми» [1, ст. 2].

Проте ГРДУ вперше як розлад був описаний у 1902 році англійським лікарем Джорджем Стіллом, який вважав, що поведінка гіперактивних дітей викликана недостатнім моральним контролем. [2, ст. 2].

В процесі чисельних досліджень у цій сорері накопичено велику кількість інфрормації, що стосується цієї теми, проте на цей час вона розкрита не повною мірою.

Виділення не вирішених раніше частин загальної проблеми. Аналіз літератури дозволяє зробити висновок, що психологічні особливості гіперактивної дитини старшого дошкільного віку значно відрізняються від дошкільника з типовим розвитком. Адже такі малюки є дуже активними і непосидючими, їм важко стримати свою увагу, вони часто відволікаються на сторонні подразники.

Цей вік $€$ сенситивним періодом в онтогенезі самосвідомості, коли починають фрормуються нові компоненти структури особистості, специсрічні саме для цього вікового періоду. Розвиток здібності до спілкування як основи взаємостосунків в дитячому колективі - це найважливіша передумова успішного становлення особистості дитини, проте це не $є$ властивим дошкільнику з гіперактивністю, адже такі діти під час спілкування є надто балакучі.

$\mathrm{He}$ дивлячись на те, що вони проявляють інтерес до спілкування, невміння себе контролювати може призвести до суперечливості. Через це у дітей часто виникають конорлікти з однолітками.

Мета статті полягає в обґрунтуванні психологічних особливостей спілкування дошкільника 3 гіперактивним розладом 3 дефіцитом уваги з однолітками.

Виклад основного матеріалу. ГРДУ є одним із поширених поведінкових розладів у дітей дошкіль- ного віку. Він має багато назв і синонімів, зокрема: «мінімальна мозкова дисфункція», «синдром психомоторного розгальмування», «гіперкінетичний розлад» та інші.

За даними досліджень, вчені виявили, що гіперактивний розлад 3 дефріцитом уваги властивий як дівчаткам, так і хлопчикам дошкільного віку.

Також варто зазначити, що гіперактивність $€$ досить розповсюдженою проблемою у віковому розвитку дітей дошкільного віку. I саме в ранньому дитинстві можна виявити причини ГРДУ.

$€$. Суковський вважав, що ГРДУ $є$ спадковим розладом, оскільки часто такі малюки народжуються в сім'ях, де ці особливості розвитку мають його батьки або інший близький родич. Водночас психологи І. Лангмейєр та 3. Матейчик аналізують соціальні чинники виникнення гіперактивності і виділяють серед них педагогічну занедбаність і такі негативні фрактори, як недостатня освіченість батьків, неповна сім'я, недостатність материнського догляду [3, ст. 46].

Причини гіперактивного розладу з дефіцитом уваги у дітей дошкільного віку є індивідуальними, але здебільшого це поєднання різних фракторів, серед яких головний - спадковість. Як зазначав $€$. Суковський, спадковість $€$ одною з причин цього синдрому, проте до гіперактивності у дитини можуть призвести і проблеми, пов'язані із вагітністю матері (стреси, алергія).

Л.С. Алексєєва ще в 1997 році зауважила, що гіперактивні діти мають величезний дефріцит фрізичного та емоційного контакту 3 матір'ю, що $€$ й актуальним і сьогодні. Через свою підвищену активність вони як би самі «йдуть», відсторонюються від таких контактів з матір'ю, але насправді глибоко потребують їх. Через відсутність цих важливих зв'язків найчастіше й виникають порушення в емоційній сорері: тривожність, невпевненість, збудливість, негативізм. А вони своєю чергою відбиваються на умінні дитини контролювати себе, стримуватися, бути уважним, перемикатися на інше.

У дитини, в якої виявлений гіперактивний розлад 3 десріцитом уваги, відмічаються шість і більше перелічених симптомів. 3 часом у 70-80\% людей, які мали цей синдром у ранньому дитинстві, він проявляється і в дорослому віці. Лише у 20\% симптоми ГРДУ, за дослідженнями €.І. Суковського, стають непомітними [4, ст. 19].

Серед особливих рис поведінки у дітей дошкільного віку з синдромом гіперактивності можна виділити такі:

- дуже активні;

- надзвичайно бурхливо реагують на довколишній світ;

- дуже швидко сердяться і часто засмучуються;

- не можуть втримати увагу; 
- часто не слухаються батьків, вихователів;

- важко заводять дружбу через імпульсивність і непослідовність [4, ст. 20].

Для вивчення спілкування та взаємовідносин дітей дошкільного віку з ГРДУ з однолітками був використаний педагогічний експеримент, в процесі якого були використані такі методи дослідження, a came:

1. Аналіз та узагальнення літературних джерел.

2. Педагогічне дослідження контрольної та експериментальної групи на цю тему.

3. Опитування (бесіда, анкетування).

Під час дослідження експериментальної та контрольної групи були використані такі методики, як колірний тест Люшера, розроблений швейцарським психологом Максимом Люшером. Другим ми обрали методику «Сходинки», яка була створена автором В.Г. Щур. Наступна методика «Дерево» - Розроблена Джоном і Дайаном Лемпен. А також під час експерименту вихователям закладу дошкільної освіти було надано анкету, яка була запропонована Андрейко Богданою Володимирівною.

Одна з перших методик, яку ми обрали, - тест Люшера. Цю методику ми обрали для того, щоб виявити емоційні установки гіперактивних дітей дошкільного віку по відношенню до однолітків.

У тесті Люшера йдеться про те, що досліджуваному треба обрати 3 восьми кольорів той, який найбільше подобається. Картку з вибраним кольором слід відкласти в сторону, перевернувши кольоровою стороною вниз. Потім треба обрати 3 решти семи кольорів найбільш приємний. I так до кінця. Реципієнт обирає з таких кольорів, як синій, зелений, червоний, жовтий, коричневий, сірий, чорний, оріолетовий.

У результаті проведеного дослідження за даною методикою, якщо основні кольори, а саме синій, зелений, жовтий, червоний, знаходяться в 1-й - 5-й позиціях, вважається, що ці потреби певною мірою задовольняються; якщо вони в 6-й 8-й позиціях, має місце який-небудь конолікт, тривожність, незадоволеність через несприятливі обставини. Однак той колір, який відхиляється, досліджуваним може розглядатися як джерело стресу.

Наступна методики - «Сходинки». За допомогою неї ми можемо виявити систему уявлень дитини про те, як вона оцінює себе сама, як, на її думку, її оцінюють інші люди і як співвідносяться ці уявлення між собою.

Методика «Дерево» спрямована на визначення місця дитини в колективі. Дітям дошкільного віку пропонуються аркуші з готовим зображенням сюжету: дерево, на якому розташовуються чоловічки. Кожна дитина одержує лист із таким зображенням (але без нумерації фрігурок). Вони повинні обрати дві фрігурки. Червоним кольором вони обводять того чоловічка, що нагадує їм їх, який $€$ схожий на них. Зеленим кольором вони обводять ту фрігурку, якою б хотіли бути або на чиєму місці хотіли б знаходитися.

В результаті дослідження ми можемо визначити ставлення гіперактивної дитини до однолітків, а також, чи комфортно їй на обраному нею місці.

Для визначення оцінки рівня спілкування гіперактивної дитини дошкільного віку з однолітками ми обрали «Анкету для вихователів». У цій анкеті $€$ одне твердження, а саме «Оцініть рівень спілкування дитини з однолітками». Вихователь оцінює малюка за десятибальною шкалою.

Дослідження було проведене в закладі дошкільної освіти (ЗДО) №134 у місті Львові. Загальна кількість досліджуваних становить 23 особи, з них 11 гіперактивних дітей дошкільного віку, які входили до експериментальної. До контрольної групи входило 12 дітей. Вибіркові групи складають діти дошкільного віку з повних, неповних, змішаних сімей та сім'ї, де батьки перебувають за кордоном. Середній вік усіх реципієнтів - 6-7 років.

На підставі отриманих результатів, ми зробили такий висновок, що майже усі діти дошкільного віку з типовим розвитком та з ГРДУ, а саме 91\% експериментальна, 93\% - контрольна група, не схильні до депресивного стану, а навпаки, є комунікативними та товариськими.

Враховуючи самооцінку, за результатами дослідження ми можемо сказати, що у дітей з гіперактивним розладом 3 дефіцитом уваги вона більш висока, ніж у дошкільників з типовим розвитком, хоч і спілкуватися їм з однолітками набагато складніше. Проте ми визначили, що дітям з експериментальної групи коморортно знаходитися у цьому середовищі, однак $є$ діти 3 гіперактивністю, які надають перевагу бути на одинці самим 3 собою.

Оскільки, як ми наголосили вище, що діти дошкільного віку з ГРДУ проявляють інтерес до спілкування, проте у них виникає невміння себе контролювати, а це може призвести до суперечливості. Такі діти під час спілкування надто балакучі, щось розповідаючи, легко втрачають думку, бувають непослідовними; часто, не договоривши про щось одне, починають розмову про зовсім інше.

Таким чином, спираючись на результати дослідження, ми можемо сказати, що діти з гіперактивним розладом з дефріцитом уваги є впевнені в собі, їм подобається спілкуватися з дітьми, які їх оточують, а також їм коморортно в цьому середовищі.

Проте не потрібно забувати, що таким дітям важко підтримувати контакт з однолітками, адже дітям 3 типовим розвитком їх важко зрозуміти, через їхню імпульсивність.

Висновки. Підсумовуючи все вищенаведене можна сказати, що результати опитування показали, що у дітей з ГРдУ набагато вища самооцінка, ніж у дошкільників з типовим розвитком. 
Також такі діти більш товариські, комунікабельні, проявляють інтерес до спілкування з однолітками з типовим розвитком.

Таким чином, спираючись на результати дослідження та проаналізувавши праці вчених, які займалися даною проблематикою, ми можемо впевнено сказати, що самооцінка впливає на спілкування з оточуючими, не важливо, чи це дитина 3 гіперактивним розладом 3 дефріцитом уваги, чи 3 типовим розвитком. Адже дошкільники, які $\epsilon$ закриті в собі, надають перевагу бути наодинці та не $є$ зацікавлені у комунікації з однолітками. Їх надмірна імпульсивність стає перепоною під час спілкування з однолітками, адже вони під час спілкування надто балакучі, проте, щось розповідаючи, легко втрачають думку, бувають непослідовними; часто, не договоривши про щось одне, починають розмову про зовсім інше. У дошкільному віці це впливає на відносини дітей з однолітками, однак 3 часом майже у 40\% дітей з ГРДУ рівень розвитку поведінкової ссрери та психічних процесів поступово досягає вікової норми.

\section{БІБЛІОГРАФІЧНИЙ СПИСОК:}

1. Алєксеєва І.В. Гіперактивні діти:корекція поведінки / Ірина Алєксеєва, Марина Калшикова. Київ : Шкільний світ. 2011. 96 с.

2. БрязгуновИ.П.,КасатиковаЕ.В.Непоседливый ребенок, или Все о гиперактивных детях. Москва : Психотерапия, 2008. 202с.

3. Дуткевич Т.В. Дитяча психологія. Навчальний посібник. Київ : Центр учбової літератури, 2012. 424 c.

4. Заваденко Н.Н. Гиперактивность и дефицит внимания в детском возрасте. Москва : Издательский центр «Академия», 2005.

5. Кирилова О.О., Бєляєва О.Е. Гіперактивна дитина / іл. О.В. Зеркалій. Харків : Вид. група «Основа», 2018. 176 с. : іл. (Серія «А мій не такий, як усі»). 